\title{
Climate wars and fat wars: A new role for law
}

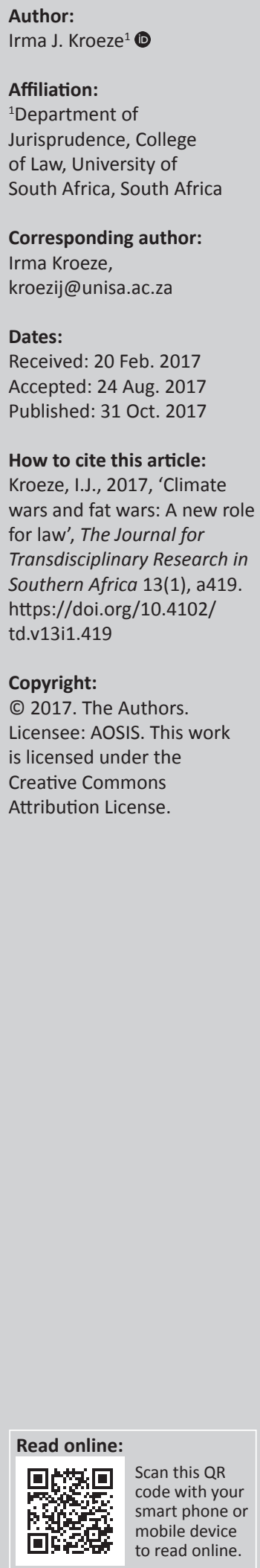

\begin{abstract}
Public trust in science is eroding because of a number of conflicts. In the sphere of climate science and of nutrition science, a basic methodological difference between scientists has escalated into what can be called wars. These wars are the result of influences such as personalities of leading scientists and powerful commercial and political interests. The wars have escalated to such an extent that leading scientists are being threatened with legal action and disciplinary procedures for advocating divergent views. These legal processes are not primarily about the procedural aspects of their actions, but are couched as being 'about the science'. This means that legal processes are being used to 'settle' the science - something that the law has never been required to do. This new role for law has implications for legal education and requires that lawyers become more capable to understand empirical research.
\end{abstract}

\section{Introduction}

It is no secret that science is in trouble. More precisely, science is in trouble in terms of the public's perception of science. The faith in science that was such a characteristic of the Enlightenment has been seriously compromised and public mistrust of scientific findings is particularly noticeable (Saltelli 2016). This distrust comes to the fore in public debates, but specifically on social media and in popular science writing (Olson 2009). It is partly the result of false or misleading reporting on scientific findings in the media where they are represented as contradictory or short-lived (Brown et al. 2014:563-565). For example, not a week goes by without some reports on which foods are good or bad for you (Hingston 2016). This results in people rejecting all findings on the basis of 'oh, they'll just change their minds again'. This is frustrating but it is not the main focus of this article. The main focus of this paper is on the intersection between climate science, nutrition science and law.

Dealing with this intersection requires a multidisciplinary approach. In fact, as will become clear in this article, climate science and nutrition science are unavoidably multidisciplinary. And, as has been argued elsewhere, legal practice and research are also multidisciplinary:

Multidisciplinarity is not only possible in law, it is something legal researchers regularly do, have done and will continue to do. Because law is a social artefact, the consideration of legal issues and problems will always and necessarily require looking at socio-political and economic factors, for example. This is a conscious or unconscious mirroring of what courts do. (Kroeze 2013:35-65)

This multidisciplinarity inevitably results in methodological differences between the various scientists and disciplines in this type of research. These differences in research methodology will briefly be discussed in the next section of this article. And, usually, these differences will result in debates that most people outside the discipline will be unaware of.

However, as the 'Climate wars and fat wars' section of this article will explain, certain events in the domain of climate science and nutrition have resulted in the debates taking on the appearance of wars. And the further developments following on these developments have now made it inevitable that lawyers will have to become more up to date on the complexities of these debates or wars. If the developments discussed below become widespread, lawyers acting in these cases will not be able to fall back on familiar, black-letter law concepts and constructs. Inevitably, their involvement will be not only about the law, but also about climate science and nutrition science. It is this connection that will be explained in this section. Finally, the 'Conclusion: Law, politics and science' section will draw some conclusions from the above regarding the way law is viewed and will explore the new role law and lawyers will play in these conflicts.

\section{'The' scientific method}

Many attempts have been made to account for the differences between disciplines and the distinctions between sciences, namely the natural, social and human sciences. These attempts are 
sometimes based on historical explanations, sometimes on the subject matter of the different sciences and sometimes merely ascribed to convention (Anderson 2003:219-234; Collini 2012:23-26; Frühwald et al. 1996). However, it has been argued elsewhere that the differences can best be ascribed to the methodological approaches of these sciences (Kroeze 2013:42). This argument will not be repeated here.

Generally speaking, methodological approaches in science can broadly be divided into two groups: rationalism (or deduction) and empiricism (or induction) (Gorham 2009:55; Tarnas 1991:59). Rationalism starts from the idea that empirical observation alone cannot be the foundation of knowledge and therefore scientific knowledge comes from rational thinking and logic. This is sometimes followed by observation but not always. Empiricism takes the opposite view and requires physical observation as the basis for knowledge. In brief, rationalists argue that knowledge is prior (a priori) to observation and empiricists argue that knowledge flows from observation and is therefore the result (a posteriori).

Despite Kant's insistence that knowledge must be a combination of rationalism and empiricism (Kant 1997:22, 31 ), it is mainly empiricism that, with the advent of modern science, came to be seen as 'the' scientific method. This method is the idea that scientists develop theories and hypotheses and then test them against observation and by replicable experimentation. It should be clear that many disagreements in science flow from methodological differences. For an empiricist, rationalist arguments may indeed sound unscientific and, on the contrary, insistence on empirical research would be incomprehensible to a rationalist researcher (such as in law).

To this explanation should be added the observation that most disciplines exist on a continuum between rationalism and empiricism. At one end of the spectrum are the most empirical sciences (e.g. geology, astronomy and chemistry), while the humanities (e.g. language, history and mathematics) are at the other end. As Kant states: 'mathematical propositions are always judgements a priori, and not empirical, because they carry with them necessity, which cannot be obtained from experience' (Kant 1997:13). Most sciences (e.g. medicine, nutrition and computer science) fall somewhere in the middle, with law being more rationalist than empiricist. This alone explains why lawyers (and philosophers) often have a hard time understanding empirical research.

The point of departure in this article is that seemingly contradictory findings in science are often the result of methodological differences and not necessarily of sloppy scientific work or fraud (although that is also sometimes present). Scientists can and do come to totally opposite findings, sometimes based on the same sets of data. How and why that happens is interesting as a background to the more important point that needs to be made. This more important point is that when some or other version of scientific findings is declared the 'settled' science or the 'authoritative' version, science loses its credibility. And it is interesting that in sciences where this has happened, the course of events has been very similar. It is hoped that a study of two examples below will provide proof of this. The further interesting aspect of these events for present purposes is the involvement of law and legal processes in how these events are being played out.

\section{Climate wars and fat wars}

Traditionally people refrain from discussing things that they know will cause conflict in a social setting. These usually include topics like politics, religion and how to raise children. But recently two other topics have become as likely to cause arguments, especially if there are sceptics present. These are climate change (or global warming) and nutrition (especially discussions about fat). The problem becomes particularly acute when certain positions are accepted as 'settled science' and someone questions the scientific validity of that position. It should be pointed out that science is never 'settled'. It is the job of scientists to try to falsify their own and others' findings, but more on this later.

\section{Climate wars}

The first thing to realise in discussions on human-induced or anthropogenic global warming is that there is no such thing as 'climate science'. Scientists from various disciplines study specific aspects of climate and they include meteorologists, atmospheric physicists, chemists, geologists, historians, literary scholars, mathematicians, computer scientists, statisticians, engineers, economists, sociologists and lawyers (Carter 2010:317). It is therefore a group that includes the whole spectrum from empiricists to rationalists. This simple fact is the reason why methodology becomes such a major factor in disagreements. It also makes a multidisciplinary approach inevitable.

The climate change debate revolves around two questions: (1) whether there has been unprecedented global warming, especially in the previous century, and (2) if so, is this because of human activity, namely the burning of fossil fuels? The problem with the first question is: how would anyone know? After all, reliable thermometer readings are only available for certain, very small, parts of the world and then only for about the last 150 years. The answer is proxies - scientists use other things as stand-ins for thermometer readings. Proxies for temperature range from tree rings to $\delta \mathrm{D}, \delta^{18} \mathrm{O}$, oxygen isotopes, fossilised plants, ice wedges, changes in glacier terminus and even narwhals. And that is where things start to get interesting.

Scientists have known from about the 1950s more or less what the past climate and temperature looked like. Very simply, it can be represented by the graph from the 1990 First Assessment Report of the Intergovernmental Panel on Climate Change (IPCC). The IPCC was established in 1988 by two United Nations Organisations, the World Meteorological Organization 
and the United Nations Environment Programme to assess 'the scientific, technical and socioeconomic information relevant for the understanding of the risk of human-induced climate change' (IPCC n.d.b). This original graph showed a Medieval Warm Period between 1000 and 1500 AD (when it was warmer than today), followed by a Little Ice Age (IPCC n.d.a:202). But from about that time perceptions started to change because of a number of conferences organised by the United Nations. Note that the changes were not the result of scientific doubt but were as a result of the mandate of the IPCC. The whole impetus behind the emerging climate science was therefore political from the start (Kroeze 2015:817-828; West 2017).

However, in 1998 a paper (MBH98) was published that seemed to overturn the accepted climate science and history and show catastrophic global warming in the late 20th century (Mann, Bradley \& Hughes 1998:779-787). It also somehow managed to erase the Medieval Warm Period and the Little Ice Age. This paper produced a different graph that was also used in a popular film (Guggenheim 2006). The authors of MBH98 used proxies ranging from tree rings (Steyn 2015:177 for criticism) to real temperature recordings to rainfall reports. These data were then combined and analysed using a specific computer algorithm to reproduce past temperatures and forecast future patterns. It is therefore a mixture of empirical data (the proxies) and rationalist methodology (computer science and statistical methods). The IPCC's alarmist projections of global warming are almost entirely based on this methodology.

There are huge problems with this study as was pointed out by various authors and their criticisms are too long to repeat here (Steyn 2015), but it makes for interesting reading (McIntyre \& McKintrick 2003:751-771; Montford 2010:55-87). Since the MBH98 paper was released, a number of other graphs have surfaced, showing up to 400000 years of geological reconstruction of past temperatures, based on ice cores taken from Antarctica and Greenland (Murdoc n.d.). These confirm the Medieval Warm Period and the Little Ice Age as well as high temperatures in eras long before humans started burning fossil fuels.

It should be apparent that there are vastly differing opinions on the two questions stated at the beginning. There are many reports and articles stating that $97 \%$ of scientists agree that man-made global warming is real. The disagreement sketched out above shows that this is not true. There is literally NO consensus on whether there has been unprecedented global warming given the past geological history. There is also NO consensus on whether human activity causes global warming based on high levels of warming long before humans started burning fossil fuels. And that is how science should work (Popper 1989, 2002) consensus is the language of politics, not of science:

Let's be clear: the work of science has nothing whatever to do with consensus. Consensus is the business of politics. Science, on the contrary, requires only one investigator who happens to be right, which means that he or she has results that are verifiable by reference to the real world. (Watts 2010)
More importantly, in the disagreement between the two sides, the methodological differences loom large. The position of the 'alarmists' is based on data sets and computer modelling (Balling 2005:50-71; Christy 2005:72-105; Von Storch et al. 2013) - a decidedly rationalist methodology. In contrast, the 'denialists' base their position on geology and observed temperatures rather than models (Douglass et al. 2007; Hartman 2002:811-812; Wild 1999:27361-27371), which of course is an empiricist methodology.

What is more interesting than the lack of consensus is what happened after this paper was published. Instead of responding to criticisms in a scientific way, the authors of MBH98 resorted to tactics more typically seen in the cutthroat world of politics. They started off by refusing to make their data and computer code available, and then descended into interference with peer review and editorial policies (Roux \& De Beer 2016 on general problems with peer review), blocking contrary positions (Morano 2016), influencing grant decisions, ad hominem attacks and even downright fraud (Delingpole 2011; Isaac 2012). This is known because these tactics were revealed in emails that were either leaked or hacked from the Climate Research Unit in a scandal that would become known as Climategate (Montford 2010:402449). These were personal emails of the authors of MBH98 and showed them discussing a series of dirty tricks. These are too long to repeat here, but well worth reading (Bell 2016).

All of this would have remained in the realm of a local skirmish had it not been for the role of the IPCC. It is important to note that the IPCC was established to study the extent of 'human-induced climate change' and not whether humans cause global warming (IPCC n.d.c, Section 2 of the principles governing IPCC work). In other words, the idea of human-induced global warming was accepted as a priori fact, which provided the IPCC with its raison d'être. Any attempt to falsify that paper or anthropogenic global warming would threaten the existence of the IPCC and its vast bureaucracy, not to mention its power to determine policies and treaties, set targets and prescribe to national governments. That is why Principle 15 of the Rio Declaration actually states that 'lack of full scientific certainty' is no reason for postponing the onerous measures proposed (United Nations n.d.). This is the 'precautionary principle' in action. Of course, scientists equally have a vested interest in keeping the grant-generating machine running, so they are not particularly interested in rocking the boat either. In the USA alone, government funding for anthropogenic global warming research in the years 1993-2003 reached \$2 billion (Hinderaker 2014; Rose 2016).

On the other end of the scale, climate change 'deniers' were being vilified, not invited to or disinvited from conferences, personally attacked and so forth. Foremost scientists lost their funding and found it hard to get their papers published (Montford 2010:107-175). Governments meanwhile were using the bogus $\mathrm{CO}_{2}$ targets to subsidise costly wind and solar power plants and to extract more taxes from citizens to meet the 'targets' (National Committee on Climate Change 
1998; Treasury 2013; Treasury 2011 for South African targets). How these taxes are being used to 'fight' global warming is never explained.

From a legal perspective, however, there are two developments that are far more interesting. The most extreme of these is the call in America to prosecute scientists sceptical of anthropogenic global warming under the Racketeer Influenced and Corrupt Organisations Act (Legal Resources n.d.; Delingpole 2011; Von Spakovsky 2016). This is the Act that was eventually used to prosecute Al Capone for racketeering which has as its goal the prosecution and defence of individuals who engage in organised crime'. In South Africa, the Prevention of Organised Crime Act 121 of 1998 fulfils the same function. So far this is only a theoretical possibility and no one has actually been prosecuted yet, but it is indicative of a mindset where to disagree with the 'settled science' is regarded as criminal.

The second development is much more real and practical. In 2012, Mann (one of the authors of MBH98) sued journalist Mark Steyn and other parties for 'defamation of a Nobel Peace recipient' (Mann 2012). Steyn had, in a blog post, poked fun at the hockey stick graph, calling it 'fraudulent', and the defamation suit was the result (Steyn 2012). Mann has since withdrawn his claim that he was awarded the Nobel Prize (because clearly he wasn't) but still insists that the blog was defamatory (Carvin \& Dick 2017). It is interesting that American courts have generally taken the position that 'merely rhetorical hyperbole' or 'vigorous epithets' must be regarded as statements of opinion and not statements of fact (Letter Carriers v Austin, 418 U.S. 264, 284-286 [1974]; Milkovich v Lorain Journal Co., 497 U.S. 1, 17 [1990]). It seems likely that Steyn's remarks will fall into that category and it seems unlikely that the claim will succeed. But Mann has taken the position that what this is really about is him 'taking a stand for science' against 'climate deniers' who are, presumably, not scientific (Banerjee 2013). And while the case has now become bogged down in legal technicalities (Popehat 2014), it seems inevitable that the case will not be so much about defamation, but rather about whose version of 'the science' is more reliable and should be accepted (Steyn 2015:184). This presents a fairly unique challenge in that lawyers for both sides will have to engage with scientific concepts and disagreements. Seeing that law is primarily a rationalist science (Kroeze 2013:44-45), the implication is that lawyers will be required to engage with empiricist sciences and studies.

Therefore, in climate science, the debate has gone from being one about simple and small methodological differences to a situation where to voice a dissenting opinion might land a scientist in jail or sued for defamation, with all the cost and potential consequences attached. And this has huge implications for the role of law. Disagreements between scientists are nothing new. What is new is scientists are using legal processes to attempt to 'settle' the science.

\section{Fat wars}

The climate debate is fairly recent, but the debate in nutrition is old (Howick 2016). As is the case in the climate wars, scientists from various disciplines study nutrition and they include medical doctors, nutritionists, statisticians, exercise specialists and analysts. It therefore also requires a multidisciplinary approach. The contemporary debate in nutrition is the result of the rise of cardiovascular disease in the West and the attempt to discover what food, if any, is responsible for the disease. As with the climate war, the nutrition debate is, broadly speaking, between two sides. One side argues that the most dangerous macronutrient in food for disease is saturated fat. It must be pointed out that when speaking of fat (and saturated fat), it refers only to natural fats that come from animals and plants. It does not include industrial seed oils or trans-fats. It should also be pointed out that all natural fats contain all three kinds of fat (saturated, mono-unsaturated and polyunsaturated fat). There is not a single natural fat that only contains saturated fat (Harcombe, Baker \& Davies 2013:240-244). The other side argues that the bad guy is not fat but carbohydrates (Joseph 2016). And once again the differences started out as methodological arguments.

There are two kinds of approaches in nutrition research: clinical trials (empiricist) and epidemiological studies (more rationalist than empiricist). In nutrition research, as in medical research, the gold standard is the randomised controlled trial. This research methodology is mostly used for testing of drugs and there are basically five requirements. In the first place, there must be two groups of test subjects: intervention group (where medicine is changed or introduced) and control group (where a placebo is administered). In the second place, the test subjects must suffer from the same disease but they are randomly allocated to the two groups. In the third place, the test must be double-blind so that neither the test subjects nor the researchers know who is in which group to exclude the placebo effect. In the fourth place, the test group must be large enough so that the results are not just chance. And in the fifth place it must last for long enough that side effects and so forth will have time to come to the fore. It is emphatically empiricist.

However, it is clear that this type of research is not always possible in nutrition research. The problem is that you would have to tightly control what people eat for a long time and it cannot really be blind. People tend to notice if they are eating butter rather than margarine, beef rather than soya and cheese rather than tofu. And it really cannot go on for very long, because you would have to lock people up and force them to eat what you gave them and it will not be long before boredom sets in. Although there have been some trials of this kind on mental patients (Frantz et al. 1989:129-135; Miettinen et al. 1972:1266-1267), they were probably unethical. Furthermore, these kinds of studies did not even establish a correlation between saturated fat and disease and can probably not establish causation (Teicholz 2014). 
The most interesting trials of human nutrition that come close to randomised controlled trials are the ones that were undertaken during the first half of the 20th century. These are not really clinical trials but are studies where researchers lived with peoples or tribes who were still eating traditional diets. In the studies of Stefansson (1969), Shaper (1962), Mann, Shaffer and Anderson (1964), Mann et al. (1972), McGarrison (1936), Hrdlička (1908), Prentice (1923), Malhotra (1967) and the Roseta community (Stout et al. 1964:845-849), the conclusion was the same: a diet consisting of up to $80 \%$ saturated fat was either protective against heart disease, cancer and stroke or neutral. These studies are the kinds of studies that are now probably no longer possible as very few communities still eat these traditional diets.

Given that clinical trials of the kind described above are very expensive and probably unethical (as in the case of the mental patients), this leaves nutrition scientists with two other clinical or empiricist options. The first is animal trials, mostly done on rats or rabbits in very small numbers for a short time. And, as Fung (2016a:214) states: 'We are not mice. We are not rats. We are not chimpanzees or spider monkeys. We are human beings and therefore we should consider only human studies'. There are two examples of this from history. The first is the 'experiment' that started the whole cholesterol scare in which Russian researchers fed rabbits (whom they had previously poisoned) a diet rich in saturated fat (Anitschkow \& Chalatow 1913:1-9). Not surprisingly, they died and had lesions in their arteries. Obviously not only do rabbits not normally eat saturated fat, but one would assume that poisoning them first is a bad idea that would skew the results. The second is recent newspaper headlines that trumpeted that the Paleo diet makes you fat (Dold 2016). It should be pointed out that the headline was based on a study that was done on only nine mice and they became fat when fed a diet that was not even remotely Paleo (Lamont, Waters \& Andrikopulos 2016).

This leaves the last option, namely an epidemiological study or a case study (Aschwanden 2017). This is a mixed methodology, but it is more rationalist, as will become clear. Originally developed to discover the source of epidemics (such as cholera), in nutrition research it is used to look for specific foods that are linked to 'hard end-points', that is, death. That is why these studies are usually done on older populations - they tend to die quicker - but what that says for a healthier, younger population is less clear. There are two famous examples of this from the history of nutrition research.

The first is the famous seven countries study of Keys (1980). Keys's hypothesis was that saturated fat in food would lead to cholesterol in the blood and this would lead to coronary heart disease. And he produced the famous, and much-quoted, graph that showed a perfect correlation between diets high in saturated fat and heart disease in seven countries (Keys 1953:118-139). There are two problems with this. In the first place, he cherry-picked the seven countries used in his study. When the data from all the countries he had data for were added, there was no correlation (Yerushalmy \& Hilleboe 1957:2343-2354). In the second place, the data were as strong (or as weak) for a correlation between heart disease and consumption of sugar (Yudkin 2016).

The second example comes from Framingham, a small town in Massachusetts. Based on the same hypothesis, this study included a large number of people from the town. They are now on the second or third generation of test subjects and people are subjected to what is known as food-recall questionnaires and blood tests every few years. After 1 year, the directors of the study confidently concluded that total cholesterol came from fatty food and this was a reliable predictor of heart disease. In the 30-year follow-up, when more people had died, the authors however stated: 'For every $1 \% \mathrm{mg} / \mathrm{dL}$ drop of cholesterol there was an $11 \%$ increase in coronary and total mortality' (Anderson, Castelli \& Levi 1987:2176-2180). More damning is that one of the study leaders in 1992 had to admit: 'In Framingham, Mass, the more saturated fat one ate .... the lower the person's serum cholesterol ... and (they) weighed the least' (Castelli 1992:1371-1372). This is in line with other larger studies - in fact, not a single study has found a link between consumption of dietary fat and heart disease (Fung 2016a:3353). But the biggest problem with the methodology in all these epidemiological studies is that it can mostly only establish correlation, not causation, unless it meets the Bradford-Hill criteria (Hill 1965:295-300).

For present purposes, however, it is more interesting to look at what happened with these studies. Keys had, by all accounts, a very forceful personality, to put it mildly. He and a group of like-minded scientists simply took over and literally shouted down the opposition (Champ 2014:Chapter 1; Kendrick n.d.:Chapter 5; Teicholz 2014:2-5). Then the same pattern emerged as when the climate debate was declared 'settled'. Dissenters had trouble getting their papers published (Sboros 2016b), were denied appointments and grants, were not invited to or disinvited from conferences and panels, and so on (Boudreau 2016; Moore 1989:37; Teicholz 2014:93, 1153). And then, through the efforts of the US Department of Agriculture and based on Keys's flawed study, the government started telling Americans what to eat and this advice has been adopted by most other countries. In this way, Keys's flawed findings were institutionalised.

The emphasis on avoiding fat (because of Keys's influence) meant that the 'food pyramid' was based on carbohydrates (Minger 2013). And that left room for giant food corporations to step in and produce low-fat foods and make huge profits (Anonyms n.d.). These foods are then endorsed by the Heart Foundation as 'heart healthy' - something for which food companies pay the Heart Foundation handsomely (Nader 2007). As with the climate wars, there was a strong movement that we have to act now and that the health of the people demanded that this happens before there was full scientific proof that this diet is in actual fact healthy. As the US Committee on Nutrition and Human Needs stated: 'We cannot afford to await the ultimate truth before correcting 
trends we believe to be detrimental' (US Senate Committee on Nutrition and Human Needs 1976).

As with the climate wars the conflict escalated when legal action started to be taken against dissenters. In South Africa, this has resulted in a complaint being laid against Cape Town doctor T. Noakes with the Medical Council (Greene 2017; Sboros 2016a). The decision in this matter will only be announced in 2017, but the possible consequences for the individual doctor (and A1-rated scientist) could be dire. His legal team acted pro bono, otherwise the cost would have been prohibitive. In Australia, the orthopaedic surgeon Gary Fettke has been instructed by their medical council not to give nutritional advice to his diabetic patients in perpetuity even if the official position changed (Fung 2016b). Should he not comply, his medical licence will be revoked. This matter has now become part of the Senate enquiry into the Australian Health Practitioner Regulation Agency complaints processes. An Australian dietitian (Jennifer Elliot) has been de-registered from her professional body for the same reason (Harcombe 2015). All these professionals argue that their advice is given on the basis of sound scientific findings. Their detractors argue that their findings are not based on the conventional advice given and they should therefore be silenced (Sboros 2017).

It should be clear that the fat wars started off as methodological differences. Whether one regards the clinical (empiricist) evidence as convincing or is convinced by the epidemiological (rationalist) evidence will depend on one's methodological preference. It is also instructive to note that, as in the case of the climate wars, these cases are often not about the technical infringement of some or other code of conduct. As the Noakes hearing showed, it is and must also be about the science. After all, if the complaint is that someone's dietary advice is 'dangerous', then evidence needs to be produced that it is indeed dangerous (Harcombe \& Noakes 2016:1179-1182). And that opens the door for a debate about the scientific correctness of a position-something very new in law and legal proceedings.

\section{Summary}

The remarkable similarity between the history of the climate wars and that of the fat wars should be obvious. It starts out as a methodological difference - or even a difference within the same methodology, something that should be normal in science. But then some event (a forceful personality, political or industry interests, professional organisations or ambitions) leads to one side being declared the 'winner' and the science is declared to be 'settled'. And when that happens, the inevitable result seems to be silencing of the opposition in what Teicholz calls the 'surprising lack of oxygen for alternative viewpoints' (Teicholz 2014:779). Science turns into a 'political battlefield'. And when the silencing is no longer effective, the 'consensus view' turns to legal processes and procedures to silence the dissenters.

\section{Conclusion: Law, politics and science}

It is surprising, but what began as fairly esoteric methodological debates have had far-reaching real-life consequences. These are consequences that should worry us as private citizens, as members of the broader scientific community and as legal practitioners, law academics and researchers.

As private citizens, the climate wars sketched above have resulted in higher taxes that directly affect everyone's pockets (SARS 2017; Treasury 2013). But the broader implications of IPCC restrictions on emerging economies can be equally devastating for the country as a whole (Lawson 2009:65-81). The direct result of the fat wars has been the acceptance of dietary guidelines by the Association of Dietetics of South Africa (Vorster, Badham \& Venter 2013:1-164). These guidelines closely mirror the American and British guidelines even though their scientific validity has been questioned (Harcombe 2016), but their introduction has not managed to stem the rising tide of obesity and diabetics in South Africa. And that does not even address the question of whether any government anywhere should be in the business of telling people what to eat.

As members of the broader scientific community, legal academics should be worried about the damage that has been done to scientific credibility through these wars (De Ruiter 2014). It has been shown that interference with the peer review system determines what the public (and other scientists) do not get to read. And this is why so many scientists choose not to publish in accredited journals any more, but post their findings online. Corporate sponsorship, industry grants for research projects and personal affiliations all serve to taint research results (Weeks 2017). The Noakes 'trial' in South Africa has led to an investigation of links between his accusers and the sugar industry (Nombembe 2017). In the legal sphere, the reward system for publication has resulted in academics publishing papers that are 'safe' or in line with universities' 'niche areas' to the detriment of robust and rigorous engagement with innovative ideas and approaches.

It is impossible to avoid the conclusion that science, and specifically peer review, has become thoroughly politicised. In the same way that Critical Legal Studies claim that 'law is politics' (Fraser 1993; Gabel 2001-2002:1141-1170; Schlag 1991:439-453), it is now possible to argue that 'science is politics'. The reasons for this are complex. To start with, Lyotard has pointed out that the meta-narrative for the presumed infallibility of science has been present since the Enlightenment (Lyotard 1984). And this scientific metanarrative is underpinned by a political narrative. In addition, once companies figured out that they can make money by appealing to scientific claims, the die was cast. As the examples from MBH98 and Keys show, certain 'scientific' findings can confer power and wealth on the originators. If these findings are also compatible with political or corporate interests, it becomes almost impossible to counter or deny them:

My skepticism is driven by the knowledge that most research is far from a dispassionate search for truth. It is usually being done for a purpose, by researchers who already have a clear end in sight. (Kendrick 2014:23) 
As law teachers, researchers and practitioners we need to be aware of the new role law is supposed to play. In terms of how we teach law, we might have to rethink Balkin's statement that not only are lawyers not taught how to think empirically, they are deliberately taught how not to think like that (Balkin 1996:949-970). But in all the cases referred to above, one or both of the parties have insisted that the hearings or cases are not about procedural or legal matters it is about the science. And that means that lawyers who were taught a rationalist methodology must now engage with empiricist studies and research. If they have no grounding in this, these legal proceedings will require a rethink of legal education, research and practice.

More importantly, scientific disputes are increasingly couched in the language of law and of rights. This has implications for how we see science - as if it is something that can be 'settled' whether in a court of law or not. But it also has implications for how we see law - as if it is capable of settling scientific disputes. And why people think the law can do this has everything to with how law is constructed. Because the scientific debate (especially the peer review process) is so compromised, the normal self-correcting scientific process cannot work. So law is being used for a purpose it was never designed for - to determine 'the truth' in science. As Spencer points out, science gives you facts, it does not give you the truth (Spencer n.d.:Chapter 2). Law is being used to settle an argument arising from scientific disagreement about the facts. As argued above, this is a new role for the law. And while lawyers are used to leading expert evidence, it is usually in well-established fields like medical negligence or compensation. The fat or carbs debate and the computer models for climate change are completely new.

However, that very neatly illustrates the popular perception of law - a perception that lawyers work very hard to maintain. It is what Pierre Schlag calls 'the standard-issue formalist dream' (1997:427-440). Law is perceived (and projected) as a neutral and value-free enterprise where formal rules and formal argumentation lead to 'correct' answers - in fact, it provides 'the truth' that science cannot. It is the carefully constructed facade of law.

\section{Acknowledgements \\ Competing interests}

The author declares that she has no financial or personal relationships which may have inappropriately influenced her in writing this article.

\section{References}

Anderson, K.M., Castelli, W.P. \& Levi, D., 1987, 'Cholesterol and mortality: 30 years of follow-up from the Framingham Study', Journal of the American Medical Association 257(16), 2176-2180. https://doi.org/10.1001/jama.1987.03390160062027

Anderson, R.L., 2003, 'The debate over the Geisteswissenschaft in German philosophy', in T. Baldwin (ed.), The Cambridge history of philosophy, pp. 219-234, Cambridge University Press, Cambridge.

Anitschkow, N.N. \& Chalatow, S., 1913, 'Über experimentelle Cholester-insteatose und ihre Bedeutehung für die Entstehung einiger pathologischer Prozesse', Zentralblat für allgemeine Pathologie und pathologishe Anatomie, 1-9.

Anonyms, n.d., Lake Vostok, viewed 22 October 2013, from http://www. thelivingmoon.com/47brotherthebig/03files/Lake_Vostok.html
Aschwanden, C., 2017, You can't trust what you read about nutrition, viewed 06 January 2017, from http://fivethirtyeight.com/you-cant-trust-what-you-readabout-nutrition/?ex_cid=newsletter/

Balkin, J.M., 1996, Interdisciplinarity as Colonization, Faculty Scholarship Series, Paper 266, pp. 949-970, viewed from http://digitalcommons.law.yale.edu/fss_papers/266

Balling, R.C., 2005, 'Observational surface temperature records versus model predictions', in P.J. Michaels (ed.), Shattered consensus: The true state of global warming, pp. 50-71, Rowman \& Littlefield, Lanham.

Banerjee, N., 2013, 'The most hated climate scientist in the US fights back', viewed 01 December 2016, from https://yalealumnimagazine.com/articles/3648

Bell, T., 2016, A major malaise of climatology is pervasive in science, viewed 01 November 2016, from https://whatsupwiththat.com/2016/05/29/a-majormalaise-of-climatology-is-pervasive-in-science/

Boudreau, C., 2016, Teicholz disinvited from food policy panel, viewed 14 October 2016, from http://www.politico.com/tipsheets/morning-agriculture/2016/03/ teicholz-disinvited-from-food-policy-panel-stabenow-grassley-let-usda-fdareview-syngenta-merger-fda-to-release-food-safety-tests-on-cucumbers-213410/

Brown, A.W., loannidis J.P.A., Cope, M.B., Bier, D.M. \& Allison, D.B., 2014, 'Unscientific beliefs about scientific topics in nutrition', Advances in Nutrition 5, 563-565. https://doi.org/10.3945/an.114.006577

Carter, R.M., 2010, Climate: The counter consensus, Stacey International, London.

Carvin, M.A. \& Dick, A., 2017, A libel suit threatens catastrophe for the climate of public debate, viewed 07 February 2017, from https://www.wsj.com/articles/ a-libel-suit-threatens-catastrophe-for-the-climate-of-public-debate-1486336417

Castelli, W.P., 1992, 'Concerning the possibility of a nut...', Archives of Internal Medicine 152(7), 1371-1372. https://doi.org/10.1001/archinte.1992.00400190013003

Champ, C.E., 2014, Misguided medicine, CDR Health \& Nutrition, Pittsburgh.

Christy, J., 2005, 'Temperature changes in the bulk atmosphere: Beyond the IPCC', in P.J. Michaels (ed.), Shattered consensus: The true state of global warming, pp. 72-105, Rowman \& Littlefield, Lanham.

Collini, S., 2012, What are universities for?, Penguin, London.

Delingpole, J., 2011, Watermelons: The green movement's true colours, Publius Books, New York.

De Ruiter, J.P., 2014, How anonymous peer review fails to do its job and damages science, viewed 13 October 2016, from http://osc.centreforopenscience.org/ 2014/05/15/anonymous-peer-review/

Dold, K., 2016, The Paleo diet might actually make you gain weight, says new study, viewed 13 October 2016, from http://www.womenshealthmag.com/weight-loss/ does-the-paleo-diet-work

Douglass, D.H., Christy, J.R., Pearson, B.D. \& Singer, S.F., 2007, 'A comparison of tropical temperature trends with model predictions', International Journal of Climatology 27, 1693-1701. https://doi.org/10.1002/doc.1651

Frantz, I.D., Dawson, E.A., Ashman, P.L., Gatewood, L.C., Bartsch, G.E., Kuba, K. et al., 1989 , 'Test of effect of lipid lowering by diet on cardiovascular risk. The Minnesota coronary survey', Arteriosclerosis, Thrombosis and Vascular Biology 9, 129-135. https://doi.org/10.1161/01.ATV.9.1.129

Fraser, D., 1993, The man in white is always right: Cricket and the law, Institute of Criminology Monograph Series No 4, Institute for Criminology, Sydney.

Frühwald, W., Jauss, H.R., Kosselleck, R., Mittelstrass, J. \& Steinwachs, B., 1996, Geisteswissenschaften heute: eine Denkschrift, Suhrkamp, Frankfurt.

Fung, J., 2016a, 'The obesity code: Unlocking the secrets of weight loss', Scribe, London.

Fung, J., 2016b, "You can't handle the truth" - Dr Gary Fettke censored for recommending low carb, viewed 14 October 2016, from https://www.dietdoctor. $\mathrm{com} / \mathrm{dr}$-fettke-censored-recommending-low-carb

Gabel, P., 2001-2002, 'What it really means to say "law is politics": Political history and legal argument in Bush v Gore', Brooklyn Law Review 67, 1141-1170.

Gorham, G., 2009, 'Philosophy of science: A beginner's guide', OneWorld, Oxford.

Greene, R., 2017, Big food vs Tim Noakes: The final crusade, viewed 05 January 2017, from http://therussells.crossfit.com/2017/01/05/big-food-vs-tim-noakes-the-finalcrusade/

Guggenheim, D. (Director), 2006, An inconvenient truth, produced by Lawrence Bender Productions and Participant Productions.

Harcombe, Z., 2015, Jennifer Elliot v Dietitians Association of Australia, viewed 14 October 2016, from http://www.zoeharcombe.com/2015/10/jennifer-elliott-vsdietitians-association-of-australia/

Harcombe, Z., 2016, An examination of the randomised controlled trial and epidemiological evidence for the introduction of dietary fat recommendations in 1977 and 1983: A systematic review and meta-analysis, Columbus Publishing, London.

Harcombe, Z., Baker, J.S. \& Davies, B., 2013, 'Food for thought: Have we been giving the wrong dietary advice?', Food and Nutrition Sciences 4(3), 240-244. https:// doi.org/10.4236/fns.2013.43032

Harcombe, Z. \& Noakes, T., 2016, 'The university of Stellenbosch/Cape Town lowcarbohydrate diet review: Mistake or mischief?', South African Medical Journal 106, 1179-1182. https://doi.org/10.7196/SAMJ.2017.v106i12.12072

Hartman, D.L., 2002, 'Tropical surprises', Science 295, 811-812. https://doi.org/ 10.1126/science.1068447

Hill, A.B., 1965, 'The environment and disease: Association or causation?', Proceedings of the Royal Society of Medicine 58(5), 295-300 
Hinderaker, J., 2014, On global warming, follow the money, viewed 12 October 2016 from http://www.powerlineblog.com/archives/2014/07/on-global-warming-followthe-money.php

Hingston, S., 2016, How the USDA screwed up the American diet - And deprived me of so much delicious butter, viewed 01 November 2016, from http://www.phillymag. com/2016/10/01/usda-dietary-guidelines-butter/

Howick, J., 2016, Aulus Cornelius Celsus and "empirical" and "dogmatic" medicine viewed 01 November 2016, from http://jameslindlibrary.org/articles/auluscornelius-celsus-and-empirical-and-dogmatic-medicine/

Hrdlička, A., 1908, Physiological and medical observations among the Indians of Southwestern United States and Northern Mexico, US Government Printing Office, Washington, DC

http://volokh.com/wp-content/uploads/2012/10/michael-mann-complaint.pdf

IPCC, n.d.a, First assessment report, p. 202, viewed 12 October 2016, from https:// www.ipcc.ch/ipccreports/far/wg_l/ipcc_far_wg_I_full_report.pdf

IPCC, n.d.b, IPCC history, viewed 21 October 2016, from http://www.ipccfacts.org/ history.html

IPCC, n.d.c, Principles governing IPCC work, viewed 21 October 2016, from http:// www.ipcc.ch/pdf/ipcc-principles/ipcc-principles.pdf

Isaac, R.J., 2012, Roosters of the apocalypse, Heartland Institute, Chicago, IL.

Joseph, M., 2016, 'How nutrition politics hid the health benefits of saturated fat', viewed 01 November 2016, from http://nutritionadvance.com/health-benefitssaturated-fat/

Kant, I., 1977, Prolegomena to any future metaphysics that will be able to come forward as science, transl. P. Carus, Hackett Publication Company, Indianapolis, IN

Kendrick, M., 2014, Doctoring data: How to sort out medical advice from medical nonsense, Columbus Publishing, London.

Kendrick, M., n.d., The great cholesterol con, John Blake, London.

Keys, A., 1953, 'Atherosclerosis: A problem in newer public health', Journal of the Mount Sinai Hospital 20, 118-139.

Keys, A., 1980, Seven countries: A multivariate analysis of death and coronary heart disease, Harvard University Press, Cambridge, MA.

Kroeze, I.J., 2013, 'Legal research methodology and the myth of interdisciplinarity', Potchefstroom Electronic Law Journal 16, 35-65. https://doi.org/10.1260/0958Potchefstroom
305X.26.5.817

Kroeze, I.J., 2015, 'Reflections on law and the politics of anthropogenic global warming', Energy and Environment 26(5), 817-828.

Lamont, B.J., Waters, M.F. \& Andrikopulos, S., 2016, 'A low-carbohydrate high-fat diet increases weight gain and does not improve glucose tolerance, insulin secretion or $\beta$-cell mass in NZO mice', Nutrition and Diabetes 6. https://doi.org/10.1038/ nutd.2016.2

Lawson, N., 2009, An appeal to reason: A cool look at global warming, Duckworth Overlook, London.

Legal Resources, n.d., What is RICO law, viewed 21 October 2016, from https://www. hg.org/rico-law.html

Letter Carriers v Austin, 418 U.S. 264, 284-286 (1974)

Lyotard, J.-F., 1984, The postmodern condition: A report on knowledge, transl. G. Bennington \& B. Massumi, Manchester University Press, Manchester.

Malhotra, S.L., 1967, 'Geographical aspects of acute myocardial infarction in India with special reference to aspects of diet and eating', British Heart Journal 29 337-344. https://doi.org/10.1136/hrt.29.3.337

Mann, G.V., Shaffer, R.D. \& Anderson, R.S., 1964, 'Cardiovascular disease in the Masai', Journal of Atherosclerosis Research 4, 289-312. https://doi.org/10.1016/S0368Journal of Atheroscte
1319(64)80041-7

Mann, G.V., Spoerry, A., Gary, M. \& Jarashow, D., 1972, 'Atherosclerosis in the Masai', American Journal of Epidemiology 1, 26-37. https://doi.org/10.1093/ oxfordjournals.aje.a121365

Mann, M.E., 2012, Lawsuit filed against The National Review and the Competitive Enterprise Institute, viewed 01 December 2016, from https://www.facebook. com/MichaelMannScientist/posts/437351706321037

Mann, M.E., Bradley, R.S. \& Hughes, M.K., 1998, 'Global-scale temperature patterns and climate forcing over the past six centuries', Nature 392, 779-787. https://doi. org/10.1038/33859

McGarrison, R., 1936, Nutrition and national health: The Cantor lectures, Faber\&Faber, London.

McIntyre, S. \& McKintrick, R., 2003, 'Corrections to the Mann et all (1998) proxy data base and Northern hemispheric average temperature series', Energy and Environment 14, 751-771. https://doi.org/10.1260/095830503322793632

Miettinen, M., Turpeinen, O., Karvonen, M.J., Elosuo, R. \& Paavileinen, E., 1972, 'Effect of cholesterol-lowering diet on mortality from coronary heart-disease and othe causes: A twelve-year clinical trial in men and women', The Lancet 300 1266-1267. https://doi.org/10.1016/S0140-6736(72)92208-8

Milkovich v Lorain Journal Co., 497 U.S. 1, 17 (1990)

Minger, D., 2013, Death by food pyramid, Primal Blueprint Publishing, Malibu, CA.

Montford, A.W., 2010, The hockey stick illusion: Climategate and the corruption of science, Stacey International, London.

Moore, T.J., 1989, 'The cholesterol myth', The Atlantic 264(3).

Morano, M., 2016, Caught on tape: UN bans skeptical journalists from climate summit for holding views not "particularly helpful", viewed 01 November 2016, from http://climatedepot.com/2016/10/21/caught-on-tape-UN-bans-skepticaljournalists-from-climate-summit-for-holding-views-not-particularly-helpful
Murdoc, n.d., Temperatures over the past 10000 years recorded in the GISP2 Greenland ice core, viewed 22 October 2013, from http://www.murdoconline. net/archives/10668.html

Nader, C., 2007, \$330,000 buys Maccas the tick of approval, viewed 14 October 2016, from http://www.theage.com.au/news/national/330000-buys-tick-of-approval/ 2007/02/05/1170524026024.html

National Committee on Climate Change, 1998, Discussion document on climate change, Department of Environmental Affairs and Tourism, viewed 30 September 2013, from http://www.polity.org.za/polity/govdocs/discuss/climate.html

Nombembe, P., 2017, New twist in Noakes case, viewed 06 February 2017, from http://www.timeslive.co.za/thetimes/2017/02/06/New-twist-in-Noakes-case?

Olson, R., 2009, Don't be such a scientist: Talking substance in an age of style, Island Press, Washington, DC.

Popehat, 2014, The procedural trial that wags the substantive dog: Update on Michae Mann's "hockey stick" trial, viewed 01 December 2016, from https://popehat. com/2014/04/23/

Popper, K.R., 1989, Conjectures and refutations: The growth of scientific knowledge, Routledge, London.

Popper, K.R., 2002, The logic of scientific discovery, Routledge, London.

Prentice, G., 1923, 'Cancer among negroes', British Medical Journal 2, 1181. https:// doi.org/10.1136/bmj.2.3285.1181-a

Prevention of Organised Crime Act 121 of 1998.

Rose, D., 2016, Exposed: The great green LSE con, viewed 01 November 2016, from http://thegwpf.com/exposed-the-great-green-Ise-con/

Roux, A.P.J., \& De Beer, C.S., 2016, On the way to the best possible science, transl. I.J. Kroeze, Sun Press, Stellenbosch.

Saltelli, A., 2016, Science in crisis: From the sugar scam to Brexit, our faith in experts is fading, viewed 03 October 2016, from https://theconversation.com/science-incrisis-from-the-sugar-scam-to-brexit-our-faith-in-experts-is-fading-65016

SARS, 2017, Motor vehicle (CO2) emissions, viewed 16 February 2017, from http:// www.sars.gov.za/ClientSegments/Customs-Excise/Excise/Environmental-LevyProducts/Pages/Motor-vehicle-CO2-emmision-levy.aspx

Sboros, M., 2016a, The Noakes Trial, viewed 14 October 2016, from http://foodmed. net/the-noakes-trial/

Sboros, M., 2016b, Victory for Teicholz in battle of butter, viewed 05 December 2016, from http://foodmed.net/2016/12/04/victory-teicholz-battle-of-butter-bmj

Sboros, M., 2017, Does DAA target dissident dietitians with fake news?, viewed 30 January 2017, from http://foodmed.net/2017/01/30/daa-targets-dietitians-withfake-news

Schlag, P., 1991, 'Foreword: Postmodernism and law', University of Colorado Law Review 85, 439-453. https://doi.org/10.2307/3481073

Schlag, P., 1997, 'Law as the continuation of God by other means', California Law Review 85, 427-440.

Shaper, A.G., 1962, 'Cardiovascular studies in the Samburu tribe of Northern Kenya', American Heart Journal 63, 437-442. https://doi.org/10.1016/0002-8703(62) 90298-3

Spencer, R.W., n.d., Climate confusion: How global warming hysteria leads to bad science, pandering politicians and misguided policies that hurt the poor, Encounter Books, New York.

Stefansson, V., 1969, The friendly Arctic: The story of five years in Polar regions, Greenwood Press, New York.

Steyn, M., 2012, Football and hockey, viewed 01 December 2016, from http://www. nationalreview.com/corner/309442/football-and-hockey-mark-steyn

Steyn, M., 2015, "A disgrace to the profession": The world's scientists in their own words on Michael E Mann, his hockey stick, and their damage to science, Stockade Books, Woodsville, $\mathrm{NH}$.

Stout, C., Morrow, J., Brandt, E.N. \& Wolf, S., 1964, 'Unusually low incidence of death from myocardial infarction: Study of an Italian American community in Pennsylvania', The Journal of the American Medical Association 10, 845-849. https://doi.org/10.1001/jama.1964.03060360005001

Tarnas, R., 1991, The passion of the Western mind, Random House, London.

Teicholz, N., 2014, The big fat surprise, Scribe, London.

Treasury, 2011, National Climate Change Response White Paper, GN 757 Government Gazette 34695, 19 October 2011, viewed 29 September 2013, from http://www. treasury.gov.za/public $\% 20$ comments/Carbon $\% 20$ Tax $\% 20$ Policy $\% 20$ Paper $\% 20$ 2013.pdf

Treasury, 2013, Carbon Tax Policy Paper, viewed 27 September 2013, from http:// www.treasury.gov.za/public $\% 20$ comments/Carbon $\% 20$ Tax $\% 20$ Policy $\% 20$ Paper\%202013.pdf

United Nations, n.d., Rio Declaration, viewed 28 September 2013, from http://www. nfft.hu/dynamic/Rio_Declaration.pdf

US Senate Committee on nutrition and human needs, "Diet related to killer disease" 94th Congress, 27-28 July 1976.

Von Spakovsky, H., 2016, Prosecuting climate change "deniers", viewed 12 October 2016, from http://www.washingtontimes.com/news/2016/apr/20/has-vonspakovsky-prosecuting-climate-change-denie/

Von Storch, H., Barkhordarian, A., Hasselmann, K. \& Zorita, E., 2013, Can climate models explain the recent stagnation in global warming?, viewed 17 October 2013, from http://www.hvonstorch.de/klima/pdf/storch_et_al_
recenttrends.pdf 
Vorster, H.H., Badham, J.B. \& Venter, C.S., 2013, 'An introduction to the revised foodbased dietary guidelines for South Africa', South African Journal of Clinical Nutrition 26(3), 1-164.

Watts, A., 2010, Aliens cause global warming: A Caltech lecture by Michael Crichton viewed 12 October 2016, from https://wattsupwiththat.com/2010/07/09/alienscause-global-warming-a-caltech-lecture-by-michael-crichton/

Weeks, C., 2017, Financial ties between nutrition researchers, Big Food raises questions, viewed 01 February 2017, from http://www.theglobeandmail.com/ life/health-and-fitness/health/financial-ties-between-nutrition-researchers-andbig-food-raises-questions/article33855434/
West, A.B., 2017, Scam: UN official confirms our WORST fears; media SILENT, viewed 12 February 2017, from http://allenbwest.com/derrick-wilburn/scam-unravelingright-eyes

Wild, M., 1999, 'Discrepancies between model-calculated and observed shortwave atmospheric absorption in areas with high aerosol loadings', Journal of Geophysical Research 104(D22), 27361-27371. https://doi.org/10.1029/1999JD900925

Yerushalmy, J. \& Hilleboe, H.E., 1957, 'Fat in the diet and mortality from heart disease: A methodological note', New York State Journal of Medicine 4, 2343-2354.

Yudkin, J., 2016, Pure, white and deadly: How sugar is killing us and what we can do to stop it, Penguin, London. 